\title{
The Writing Ecologies of Older American Activists
}

\author{
Yvonne Teems - Hofstra University \\ KEYWORDS
}

aging; writing ecologies; New Materialism; disability studies

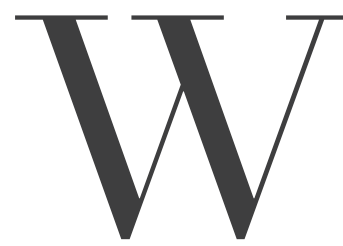

hile studying older adults appears niche in its focus on a marginalized community, this community is unique in its ubiquity - we all have the potential to age. Similarly, writing studies research on aging contributes insights relevant not only to those interested in aging, but to the field at large. Writing studies researchers have examined older adults' identity construction and their relationships with technology and medicine. Ruth E. Ray has explored the ways people use life writing to construct identity with regard to age, gender and race. Scholars have examined the ways older adults acquire technological literacy (McKee and Blair), to what extent they are technologically literate (Teems, "Evidence"), and the cultural expectations of their technological literacy as represented in public texts (Bowen). Kathryn Yankura Swacha has found troublesome metaphors for aging in public health literature, and I have identified the ways older adults internalize these types of cultural tropes ("My Body") and use literacy tactics in medical encounters to leverage power ("Seniors' Uses").

This research is not only relevant to other researchers who study older adults' literacy practices or to those who teach older adults directly. Research on the literacy practices of older adults also is at the forefront of literacy and composition studies because it is able to further the field's understanding of writing ecologies (Dobrin; Rickert; Syverson; Taylor). Ecological theories of writing assume that the subject exists within a complex system that is composed of an unlimited number of influences, such as the author's culture, background, history, and education, as well as material resources, including the author's tools and the embodiment of the author herself. Ecologies include the interactions and conversations writers have had with others, contributing to the idea that no one writes alone (Taylor). These components interact in unpredictable ways to produce writing that conventionally would be attributed to the author-subject. Researchers may find it difficult to systematically examine authorial embodiment and materiality as components of writing ecologies. Yet because older adults' bodies are marked as aging, studying them allows us to bring to the surface the role of the body within their writing ecologies, and thus contributes to our understanding of how bodies function within complex systems of writing. 
This study asks two linked questions through an interdisciplinary lens: First, what can we learn about writing ecologies by studying older adults' literacy practices? Second, what can we learn about

'Because older adults' bodies are marked as aging, studying them allows us to bring to the surface the role of the body within their writing ecologies, and thus contributes to our understanding of how bodies function within complex systems of writing." older adults by examining their writing ecologies? In this article, I examine two activist men over age seventy-five to explicate the aspects of their writing ecologies that relate to aging, ability, and materiality. To do this, I use an interdisciplinary approach that first draws connections among the mostly discrete fields of writing studies, disability studies,

and age studies. ${ }^{1}$ I collect and analyze data through community-based and feminist methodologies, and I analyze the discourse of the interviews. Finally, I discuss what is useful about examining older adults' writing ecologies for older adults and for those who work with them.

\section{Interdisciplinary Framework}

By drawing connections among the epistemological grounding in disability, age studies, and writing studies, we may find a more productive interdisciplinary approach to the phenomenon under study. Each of these fields has experienced parallel moves toward new materialism. In Rhetoric, Through Everyday Things, a 2015 edited collection that examines materiality in writing studies, S. Scott Graham identifies the move to new materialism in the humanities and social sciences broadly. He writes, "[N]ew materialisms (Coole and Frost's umbrella term) are marked by a strong interest in objects, ontologies, reality, and the concrete" (108), and in so doing they identify the shortcomings of the social turn, where human subjectivity constructs reality in lieu of material reality.

Disability studies has taken a new materialist approach to its work in recent decades. Prior to the social turn, disability studies used a medical model, where disability was a problem located in the individual's body. The social turn separated impairment from disability, defining impairment as bodily difference and disability as the socially constructed barriers that people with impairments face because of that difference. Disabled bodies only struggle in the world due to the way the world expects "normal" bodies to move and function (Shakespeare). In response to this turn toward constructivism that ignores the material body, disability studies scholars began to argue for a phenomenological interrogation of "lived experience" (Hughes and Paterson). Tobin Siebers suggested a "theory of complex embodiment" that "raises awareness of the effects of disabling environments on people's lived experience of the body, but it emphasizes as well that some factors affecting disability, such as chronic pain, secondary health effects, and aging, derive from the body" (25). In other words, while impairment often can be something to celebrate, disability studies must also acknowledge its negative effects. Siebers' new materialist focus on the body complicates the study of disability by acknowledging somatic experiences and not only disability's social construction.

Social gerontology took similar, if differently timed, turns as disability studies—one turn away 
from the body with social constructivism, and one back toward the body with new materialism. The social turn positioned aging as a social construction, but Peter Öberg brought the body back into aging in a way similar to Siebers, focusing on the material realities of the aging body. Recently, scholars have sought to bring together aging and disability studies in a special issue of the Review of Disability Studies: An International Journal that focuses on disability and aging (Conway). The fear in both fields is that a return to the body could lead us to the medical model again, and so researchers call for an understanding of both material and discursive construction of aging (Öberg; Twigg) and disability (Siebers; Hughes and Paterson).

Like disability and aging studies, writing studies has followed a similar pattern, focusing on the writer and/or text exclusive of social context (Perl; Sommers). The social turn prompted us to examine the writer in situ, yet here we faced limitations, such as the "limits of the local" that preclude an understanding of how writing in local contexts is connected to global forces, an antidote to which, Deborah Brandt \& Katie Clinton suggest, is examining the "text-as-object." Kate Vieira echoes this sentiment, noting that literacy has materiality: "literacy is not only a social product, but . . . it is also an object that actively constitutes the social" (27). To examine this phenomenon, she writes, "Brandt and Clinton encourage us to look at literacy instead of through it-precisely the work that compositionists' disciplinary training encourages" (27). In her study of immigrant families, Vieira observes literacy's inherent agency_-such as in the form of a passport—to regulate the movement of bodies across borders, and to act as an opportunity but also an obstacle.

\section{Writing Ecologies}

In writing studies, one new materialist approach to explain how material objects and bodies are implicated in the writing situation is through the study of writing ecologies. Margaret Syverson argues that writing ecologies theory attempts to account for additional variables within the writing context outside of "writer, text, and audience" (23). Writing ecologies theorists attempt to decenter the subject and to account for the agency of things, human and non-human, that contribute to the emergence of a written product. The interactions of these networked items are explained by complex systems theory. Complex systems are sets of "independent agents ... [that] act and interact in parallel with each other, simultaneously reacting to and co-constructing their own environment" (Syverson 3). Further, "because such a system is self-organizing, adaptive, and dynamic, it is not possible to predict its behavior simply by understanding its parts and their relationship to each other; a complex system defies any attempt at a strictly mechanistic explanation" (4). Syverson explains that "an ecology is a kind of meta-complex system composed of interrelated and interdependent complex systems and their environmental structures and processes" (5). As a system of complex systems, writing includes varied components that interact with one another, influencing each other and producing byproducts that are incapable of being predicted. Sidney Dobrin advances this writing ecologies theory, explaining that the complex system of writing is "fluctuating," and "one not moved toward stability" (144).

To examine the writing ecologies of the activist men in this study, I examine the Discourses ${ }^{2}$ 
(Gee) of aging and the ways they intersect with participants' descriptions of their literacy practices. Aging might be seen as a component of a networked writing ecology's "ambience" (Rickert) in which the network exists. More accurate than "Aging might be seen as a component of "environment," the concept "ambience," says a networked writing ecology's 'ambience' Thomas Rickert, "seeks to put place, (Rickert) in which the network exists." language, and body into co-adaptive, robust interaction" (904). In this study, I talk with aging activists about their literacy practices and then examine the ways an aging Discourse is threaded through the discussion. This lends insight into the ways participants' constructions of aging affect their literacy practices and the role of the body in this ecology.

\section{The Neighborhood Action Coalition}

This article examines two black men over age seventy-five who are members of a grassroots civic organization in a suburb of New York City. The civic organization, which I am calling the Neighborhood Action Coalition (NAC), serves a minority community composed of about $45 \%$ black, $40 \%$ Hispanic, $10 \%$ white, and $5 \%$ other races and ethnicities. The NAC is a community organizing group that aims to generate power in numbers of residents who have a stake in the direction of the neighborhood and to leverage that power to influence the decisions of local government, businesses, and universities. The group maintains strong relationships with some government officials and university partners but struggles to make its voice heard on all issues. Organizing leaders attribute this to a lack of representatives who listen to their concerns as well as to the neighborhood's "minoritymajority" status, as they describe it.

A coalition of community groups, the NAC meets regularly to proactively address the needs of the community and react to local government and business decisions. At the time of the interviews, the community group was focused on three main issues: enhancing local economic opportunities by working with local government to establish a workforce development site; working with the school district to address the increasing need for infrastructure expansions; and responding to a developer's plans for a new residential complex. The group's leadership team meets weekly for two hours, and the group's broader membership meets monthly.

The neighborhood's majority-minority makeup is one of the elements that brings many of the activists to the table. Organizers often cite the neighborhood's demographic makeup as part of the reason lawmakers privilege other neighborhoods with a majority white population. The majority, but not all, of the members of the leadership team identify as part of a minority group. The context of the community is important to consider as background to the following analysis of participants' discourse on aging. This article's analysis is limited to the ways participants discursively construct age and disability, which leaves other components of participants' identities, including race, underexplored. Theorists have discussed the ways in which identity, including racial identity, intertwines with literacy practices and discourse (Cunningham; Cook-Gumperz; Gardner-Chloros; Gee; Gilyard). These components of the participants' identities undoubtedly shape the discursive 
representations of their activist literacy practices and impact the ways they construct aging, yet a thorough analysis of those intersections is beyond the scope of this article.

\section{Methodology and Methods}

I engaged in participant observation of the weekly leadership team meetings for the fifteen months leading up to the interviews, and I audio recorded the latter nine months of meetings. I audio recorded one-on-one interviews with the two participants who are the focus of this study and who regularly attend the weekly meetings. The study received approval from my university's institutional review board, and all individuals who participated in the weekly meetings and interviews signed consent forms. Names of people, organizations, and places are changed and nonpertinent details of some community issues are left vague to protect the identity of the group and its members.

As feminist research, the study is transparent in its methods and reflective in practice (Fonow and Cook). The study uses an ethic of reciprocity (Powell and Takayoshi) that requires an open and evolving relationship between researcher and participants wherein the researcher takes up opportunities for giving back to participants as they become apparent. To those ends, I attended as many meetings as possible, listening mostly but offering advice in the few areas where I had expertise or connections to the university. I also served as the organization's "writer," - an interesting title given the distributed nature of writing in writing ecologies theory-drafting letters to government officials and marketing materials as needed.

Feminist researchers seek to dismantle the power dynamic between researcher and researched in many ways. Some researchers suggest recruiting participants to engage as co-researchers; for this study, asking participants to do that work would have placed an unnecessary burden on them. To ensure participants maintained control over what gets published about them, I included the following clause in the consent forms: "The researcher will allow the organization's co-facilitators to review any presentation or publication of findings prior to the release of this information to ensure that the organization's mission is not compromised." Prior to publication, the participants had an opportunity to review this article and redact or change details that might reveal the organization's identity or strategy. I worked with participants to ensure that details were not altered to the point that findings or conclusions would be jeopardized.

In this study, I treat participants' talk about civic work as a discursive representation of their civic literacy practices. ${ }^{3}$ Interviews were discussions of participants' civic work, which includes literacy practices such as going to the library, conducting research on topics important to the community, and reviewing government and school district documents in order to take a position on particular issues, as well as note taking and drafting position statements.

\section{Norman}

Norman is a seventy-six-year-old member of the NAC who worked for a nongovernmental agency during his professional life. He raised his family in Brooklyn, New York, where he became 
involved in the local school district as an active citizen. Upon moving to the New York City suburbs, he continued his involvement in his local community, most recently contributing to the study of a new development in the community and its impact on traffic, which was his specialization as a former engineer. Retired now, Norman describes his daily visits to the library as the nexus where his literacy work and his management of aging meet. He explains that in recent years he lost his wife and his daughter to cancer, and staying active in the community is one way to maintain a positive outlook on life.

For Norman, the library becomes a place where he meets his needs as a retiree. He says, Norman: It was so well. It's critical to my mind. I think reading is the best thing they invented. I think because that's the grasp of information, I'll read it. Like I do, I literally go to the library just about every day. Read a book, buy a newspaper ( $)^{4}$ Best in Business Daily, USA. It keeps you current. And it's also the practicality; it's pragmatic because you learn something from it. I'm retired so you have to be aware of your surroundings, it's ( ). Things are constantly changing that you know. As a person said, "The only thing constant is change." And you just have to be aware. There's so many things; investments, should I go here now? Where is the place you're not to go. There's markets there, there's ATF's. No, seriously. You know if you're retired you don't want to run out of your money. You're [eating] cat food. No, seriously. That's the way I look at it. So, that scares you to keep learning. To keep learning. And then you find out too that as you age you've got to keep growing. Age is not simply a number because sometimes the joints let you know they're aging. You know you're outliving the joints. But, I think you have to keep active. You have to keep your mind, body, and soul. Continuing to ( ) and that's part of it; being part of organizations, been all over the place. Real deal, it's all over.

Yvonne: Now, you mentioned going to the library. Why go to the library to read the papers instead of having them come to your house?

Norman: Okay, that's a good question. First of all, too. I'm by myself; I need social interaction. Okay, which is good. So, you don't stop, you don't go live and isolate yourself completely. You get that social interaction. I go to the East Neighborhood Library, I go to the West Neighborhood Library, I go to the North Neighborhood Library, I go to the South Neighborhood Library, I go to the Central Neighborhood Library. A lot of people they kind of see me, and they know me. And it's some interaction: "Hi, how you doing?" And so forth. They have courses there. I just took chess at East Neighborhood Library.

The library, for Norman, is a place where he manages all of the challenges of retirement and aging. He brings up four distinct features of aging in this excerpt that will be discussed in turn: retirement as a time when you lose connection to information; retirement as a time when you risk poverty; aging as a time of inactivity; and aging as a time of social isolation. The library is a place where he combats all of these challenges.

First, Norman describes retirement as a stage in life where it would be easy to lose track of what 
is happening in the world. He says, "I'm retired so you have to be aware of your surroundings. . . . Things are constantly changing." Retirement is a stage in life that is also often associated with aging because most adults retire when they reach a late numerical age. Norman reinforces this concept by sliding easily from a discussion about retirement into a discussion about aging in this same excerpt. He says, "And then you find out too that as you age you've got to keep growing."

The library helps him to stay aware of current events as it provides him with access to the latest of any periodical, such as Best in Business Daily and USA Today. Later in the interview, he says that he picks up whatever sparks his interest, including Money Magazine, Kiplinger's, and Psychology Today. When asked how the library is related to his civic engagement, he notes, "It show you how interrelated things are because I pick up an article talking about the same social issues." He notes that he picks up the local newspaper and sees an article about a development that is on the community organization's radar. He adds, "It keeps that awareness, that consciousness." Through reading these articles, he can contribute to strategizing at the NAC, which is researching the development's impact on the community and working together to come to a consensus about where to stand on the project. At a stage in life where he says it might be easy to become less informed about what is happening in the local and global communities, Norman notes that the library allows him to maintain awareness and also to use that literacy practice to be a contributing member of the community activist group.

Second, Norman connects retirement and, therefore, aging, with risking poverty, and positions the library as an antidote to that risk. He says, "If you're retired you don't want to run out of your money. . . . So, that scares you to keep learning." Norman brings to the forefront that one of the greatest material struggles of aging is adjusting to a new and often reduced level of income. He uses

"When Norman notes that 'age is not
simply a number, he argues that age is
embodied; it is more than the number of
years you have been alive. He feels his age
in pain and stiffness that he experiences
in his joints. Thus, age is not only a social
construction but also a material, lived
experience..."
the library as a space where he accesses the resources of financial literacy, reading about the stock market in magazines such as Money and Kiplinger's. He jokes that one might be reduced to eating "cat food" if one's resources were depleted, and how a thought like that "scares you to keep learning." This emphasizes that in retirement, people are limited to few options for obtaining material resources. They may have little family to rely upon, or

they may be unable to work a full-time job any longer. One way to maintain control over one's material resources is to manage what you already have saved. To do this well, Norman turns to literacy practices that he engages in at the library.

Third, Norman describes the library as a place where he can combat inactivity in all of its formsinactivity that comes with aging. He says, "And then you find out too that as you age you've got to keep growing. Age is not simply a number because sometimes the joints let you know they're aging. You know you're outliving the joints. But, I think you have to keep active. You have to keep your mind, body, and soul. Continuing to ( ) and that's part of it; being part of organizations." Age studies scholars have described different ways of measuring aging (Coupland, Coupland, and Giles), and 
Norman identifies two of them here: aging can be measured numerically but also physically. When Norman notes that "age is not simply a number," he argues that age is embodied; it is more than the number of years you have been alive. He feels his age in pain and stiffness that he experiences in his joints. Thus, age is not only a social construction but also a material, lived experience, as scholars have argued (Öberg; Twigg). He goes on to say that "you're outliving the joints," which implies that your mental sharpness might stay intact longer than your body's capacity for movement and health. Age studies scholars remark upon this idea in their description of the mask of aging (Featherstone and Hepworth), where older adults look in the mirror and do not recognize the aging body because their sense of self seems much younger.

In order to combat the effects of aging, Norman says that "you have to keep active," and "active" in this statement seems to take on multiple definitions. He had just been talking about reading at the library to stay in touch with the goings-on of the community and the stock market, and now he is talking about the need to keep "growing" despite the limitations of the joints. The library seems to provide opportunities for both mental and physical "activity" and "growth." He underscores this idea when he says, "You have to keep your mind, body, and soul." He goes on to say that "being part of organizations" like the NAC is part of what it means to be active. This relates to the interconnectedness that he points out later in the interview. Aging contributes to mental and physical inactivity, Norman argues, and literacy practices such as going to the library and participating in community groups, some of the work of which involves library research, helps him to stay active.

Later in the interview, Norman connects physical activity to library literacy practices more explicitly. While on a library computer, he checks out different articles that catch his eye. He says, "It might be something on health because that's very important especially as you age. . . . It keeps you alert, it keeps you active. You getting to the age and think . . you know exercise is critical. I try to exercise. I will sometimes exercise seven days a week." He directly connects the need to fight the physical effects of aging with physical activity, and he notes that he will read about health and exercise to inform this activity. The library seems to provide Norman with the physical activity of engaging with other humans, books, and computers; the opportunity to connect with and stay current on issues that he takes with him to community groups; and information on physical activity and health literacy.

Fourth and finally, Norman describes aging as a time when one can experience social isolation, and his literacy practices help him to stay socially connected. Like many older adults, Norman is a widower, and he lives alone. He describes how he goes to a different library every day and spends on average two hours at each one. The social interaction is essential to his quality of life: "A lot of people see me ... and they know me. And it's some interaction: 'Hi, how you doing?' and so forth." Norman emphasizes the importance of social interaction and how the library provides that in informal and formal ways: “The library atmosphere too. I'm getting the social, I'm getting the universe. They've got courses I can sign up for." He joined a chess group through one of the libraries which not only provides him with social interaction but also forces him to engage in "deep thinking."

In this example, Norman describes the norm of aging as having multiple negative qualities: lack of awareness of global and local events, financial distress, inactivity, and social isolation. Norman uses 
the library as a way to combat all of these negative consequences of aging, and the literacy practices that he engages in at the library contribute directly or indirectly to his work in the community. In highlighting aging in Norman's community activist literacy ecology, we have found that Norman even more robustly engages in literacy practices in response to his fears that aging will cause mental, financial, physical, and/or social depletion. This in turn allows him to be even more engaged in his community activist work by being more aware of ongoing community issues, networking with others in the community, and finding information that informs the activist group's decisions.

\section{Gerard}

Gerard is a seventy-eight-year-old member of the NAC and elected member of the local school board, a position he has held for almost twenty years. Of Caribbean origin, Gerard moved to New York City as a young man and worked on issues facing Caribbean immigrants in Harlem and Queens throughout the 1960s and 1970s. Throughout his adult life, he held a government job, and he became involved in his local school district when he moved to the New York City suburbs and had children.

Gerard describes himself as an active contributor to community work but notes that he is in the process of passing responsibility to the next generation.

\section{Excerpt 1:}

Gerard: I've just been sitting there observing [laughter.] And at my stage of the game, that's what it has come down to.

Yvonne: When you say my stage of the game, what do you mean?

Gerard: Well, I've been at it a long time. Some people my age are retired, I mean from civic engagement and community. I'm still involved, so I'm leaving it to younger folks to do the heavy-lifting [laughs] and stuff like that. But, wherever I'm needed or I could assist, I pitch in. I'm more or less passing it towards ( )

Excerpt 2:

Yvonne: So, that's really interesting; you say that some people would retire from civic engagement and community. Why not you?

Gerard: That's a good question, [Laughter] and the answer is I'm not ready to do that. I still think there's things that I could assist with it and contribute towards, so I continue. And, it's a good thing; it helps me, keeps me abreast of what's going on, and it's healthy. [Laughter]

Yvonne: How so?

Gerard: Well, it keeps you active to some extent; inactivity, I don't believe, is very 
good. So, I'm active and I think that's a helpful thing. And, it keeps me, my mind alert and active; I think that's helpful as well - healthful. I mean, I've been at it awhile. I've been involved in community activities since I was in my twenties.

Yvonne: Wow.

Gerard: I'm almost eighty.

Gerard's discussion of aging and practicing community activist literacy sheds light on his literacy ecology when his discourse is examined with insights from age studies.

First, Gerard's discourse in this example constructs an identity that is located between young and old. To do this he uses a "provisional continuity device" that has been discussed by age studies scholar Pirjo Nikander. She conducted interviews with Finnish men and women nearing age fifty and found that they consistently "construct provisional continuity that allows them simultaneously to acknowledge and distance themselves from factual notions of physical or psychological lifespan change" (865). Nikander found that this identity construction is not uncommon among those transitioning among age brackets. Specifically, her participants invoke a pattern in their discourse in which they deny impending change due to aging (A), then acknowledge that change is possible or inevitable, or perhaps has begun in some small way (B), but then reiterate that they have yet to experience significant change (A). Because this pattern is seen in the identity constructions of membership categories in other studies, Nikandar argues, it can support the argument that age is a membership category that is indexed discursively.

If not an exact copy of this pattern, Gerard's movement between youthful and aging categories constitutes a "provisional continuity device" (Nikander). His talk moves back and forth between a younger and older age identity category; if we were to apply the same variables, we might name it BABAB. Note how the excerpt from above weaves back and forth from an aging to a youthful membership category (clauses coded as aging are in bold; clauses coded as youthful are in italics):

Well, I've been at it a long time. Some people my age are retired, I mean from civic engagement and community [aging]. I'm still involved [youthful], so I'm leaving it to the younger folks to do the heavy-lifting [laughs] and stuff like that [aging]. But, wherever I'm needed or I could assist, I pitch in (youthful). I'm more or less passing it toward ( ) [aging]

The ABA pattern is also evidenced in the second excerpt, where Gerard is asked why some retire from community work but he does not. He does a similar type of weaving between the identity categories in this response. He notes that there are still ways for him to help advance the causes that he has worked on even though he is "almost eighty." Just as with the first excerpt, he underscores a contradiction between what he is able to offer and his numerical age. Thus, the first observation is that Gerard's talk of his activist literacy activity locates him in a transitional, liminal space between young and old.

The second observation is that Gerard's discussion of aging as a community activist is framed by metaphors of physical labor, which lends insight into the embodiment of his literacy practices. He 
notes that at his age, many people retire from community work, but he is still involved. Even though he is still involved, he leaves the "heavy lifting" to the "younger folks," which shows that he pulls back a little from his intense community engagement to allow others to take up the greater burdens. In this metaphor, the tenor or subject is the literacy work and the vehicle is physical labor. Because he says he leaves the literacy labor to younger folks, he implies that older people should not or cannot (or simply do not want to) do the heavy lifting. The metaphor underscores that there are limitations on older adults' literacy practices that are akin to their physical limitations. The use of this metaphor takes for granted that people experience physical limitations as they age, and then extends those physical limitations to the labor of literacy. By packaging physical limitations and the limitations of literacy work into one metaphor, Gerard implies a correlation between age-related limitations in the body and in literacy practice.

The metaphor also implies that, in literacy, there is physical labor. This "heavy lifting" includes attending meetings, conversing with community members, and writing emails, letters, and memos, all of which require physical energy. My observations of the NAC over the course of eighteen months allowed me to see members' bodily movements: climbing stairs (which appeared difficult for Gerard); physically gathering around a table, often late into the evening; carrying and distributing materials; taking one's place on a wooden bench in the county legislative building; standing, holding a sign, in unity with the community group at that meeting; and climbing a bus to travel to the sidewalk outside of the legislative building to stage a protest. All of these physical movements and positions, as well as selections of spatial locations, are part of participants' activist literacy practices. Gerard's metaphor reveals that the body's ability to do these activities determines one's level of literacy activity within this ecology.

In the second excerpt, body metaphors and literal body references are again bound up with Gerard's discussions of literate activity. Gerard says that his work in the community keeps him healthy: "Well, it keeps you active to some extent; inactivity, I don't believe, is very good. So, I'm active and I think that's a helpful thing. And, it keeps me, my mind alert and active; I think that's helpful as well; healthful." In this example, the line between physical and mental activity and health is blurred. He says that literacy "activity" "helps" as well as contributes to his "health." Activity in this example might be interpreted as mental but also physical, as his work in the community includes walking around high school and college campuses and attending meetings. Further, he describes his activity as "healthful," which might include both mental and physical health. This example shows that his community literacy work impacts health and body in positive ways.

Later in the interview, Gerard uses another body metaphor to describe community activist literacy work. In response to the question, "How old are you?", he says, "seventy-eight; going on seventy-nine [Laughter]. So, I've been doing this a long, long time starting with that and all the stuff like that. And, I'm from [the Caribbean]; I used to be, in my twenties, president of the State Public Affairs Council. Yeah, I've been doing this all my life, so it's in my blood." In this metaphor, the tenor is his commitment to community activism and the vehicle is his blood, and the rationale for making such a bold statement is, in fact, age. He rationalizes that community work is "in my blood" because of how long he has been doing it; he measures the length of time spent on it by comparing his age 
when he started (in his twenties) to his age now (late seventies). Ecological theories of writing reveal the co-constitutive nature of components' interactions; in this example, Gerard's engagement in community activist literacy practices produce a body whose life force includes that practice. Gerard was not born with activism in his blood; instead, his notation of the years he has spent on it show that it exists because he produced activist work for so many years. Just as his decades-long literacy practice produced a body that houses activism, the body may affect the nature and longevity of that activism. Because it is in his blood, he may never give it up; it might only stop when life does.

The observations made about Gerard lend insight into his writing ecology. Gerard constructs a distinction between active/young/capable and inactive/old/incapable, and then limits his activist literacy work in a way that locates him within the liminal space between those poles. He still participates in the work, but he does not participate as fully as he used to. Gerard also reveals some insight into the body's role in literacy activity. He identifies the body's labor as essential to this activity and notes that age reduces bodily and literacy activity. Yet his age allows him to have spent decades on this work, which makes this work an inextricable part of himself. While age is why he continues to engage in activist literacy work, it is also why he cannot do it fully, which perhaps explains his location in the liminal space between young and old.

\section{Conclusion}

In both examples, participants describe engagement in their activist literacy practices as something that is antithetical to the traditional aging experience. These tropes that equate aging with bodily decline are common in our culture. Studying older adults in film, Sally Chivers argues that aging successfully means appearing as if you are not aging at all. This trope of "aging well" implies that older people have the agency to control their health and levels of ability (Rubinstein and de Medeiros), yet this attitude has been critiqued because it does not account for variables outside the individual's control. There are problems with the "aging well" construct in that it disparages the difference that may come with aging. But it does, as I have argued elsewhere (Teems, "My Body"), acknowledge that aging may bring pain and disability, which accommodates a "complex theory of embodiment" that acknowledges the "negative and positive valences of disability" and, one might add, of aging (Siebers 5).

In joining the NAC, participants have found one way to handle what they characterize as the struggles of aging. The ways participants describe the experience of aging often run counter to disability and aging scholars' and activists' arguments that bodily difference has affordances. Yet while scholars identify the positive affordances of bodily differences, they do not deny that aging and disability can come with impairments that cause pain and discomfort (Siebers) and that are not accommodated in a society that privileges the young and abled norm. Accommodations are not always available in all sectors of American society, but the activist organization to which these participants belong appear to have some: weekly participation, while encouraged, is not required, and contribution to discussions can be as minimal as providing a listening ear. As a space that allows for accommodations in ways that the market economy does not, grassroots activism may 
offer opportunities for engagement that meets the needs of older adults where they feel that they are. Those who belong to activist organizations may find, like Gerard, that they are able to "still contribute," even if their contributions are more limited than when they were younger.

These older adults seem to find in activist organizations the "positive valences" of aging because it is age that allows them to add value to the organizations' missions. Older adults bring to activist organizations a wealth of historical community knowledge and a career's worth of working in a particular field (as Norman brought his engineering expertise) or with a particular community: both participants have volunteered in school districts for more than forty years. As retirees, they may have more time to devote to the time-consuming work of activism, where grassroots meetings happen weekly and monthly and government meetings often happen during the workday. Further, activist groups, unlike workplaces, are unlikely to discriminate based on age, as they are grateful for any unpaid volunteers ${ }^{5}$ and their success is often directly related to the number of community members who get involved. Perhaps most importantly, this organization's mission is to enact change that will divert resources to their community, one that is commonly overlooked, and participants may feel valued and valuable in contributing to those goals.

By examining the aging Discourse within discussions of activist literacy practices, we gain insight into the participants' writing ecologies. First, participants in NAC's weekly meetings engage in distributed authorship (Syverson) as members gather, talk, and strategize a joint response. Second, complex

“This organization's mission is to enact change that will divert resources to their community, one that is commonly overlooked, and participants may feel valued and valuable in contributing to those goals." systems generate products and byproducts that are unpredictable (Syverson): while the participants began their work in the community as young men, they have since found that participating provides physical and mental health benefits. This may be a byproduct that was unanticipated when they were younger, but now it has become a focal point of their engagement. Third, the participants' writing ecologies include multiple complex systems that relate to and interact with one another (Syverson). Norman says that he picks up magazines to educate himself on financial or other issues that are important to him as he ages, and in doing so, he learns more about a community issue that the NAC is addressing: "It show you how interrelated things are," he says. At this point of intersection that Norman describes, we might think about two writing ecologies intersecting, as he shifts focus from one goal (e.g., financial literacy) to another (e.g., activist community literacy) because of the topics presented in the magazine.

By looking at the ways aging is woven into the "ambiance" (Rickert) of these participants' writing ecologies, we highlight the important ways the body intersects with literacy practices, thus characterizing older adults' lived experiences as activists. Specifically, participants position bodily decline in correlation with a decline in literacy work, suggesting that they think that bodily ability and energy are essential components to the engagement of literacy practices. Participants also characterize activist literacy work as similar to exercise in that doing it maintains one's cognitive and physical health or it can be used to combat aging's effects on health. Finally, in Gerard's case, 
age creates a body that is consubstantial with activist literacy activity. This suggests a dialectical relationship between activist literacy work and physical and mental health that includes the added characteristic of a centripetal force: the more one does, the more one is able to keep doing, and the more one's body is inseparable from this activity.

Older adults' lived experiences as activists necessitate an understanding of the body, both discursive and material. The body is affected by and affects the ecology but also becomes a much more integral component to the literacy work the longer the work goes on. Through an analysis of situated writing practices, we are able to systematically trace some of the connections within the complex networks that make up these writing ecologies, furthering our understanding especially of writing ecologies' material components. 


\section{NOTES}

${ }^{1}$ While the three fields are mostly discrete, disability studies and writing studies, particularly rhetoric, have a joint history (see Brueggemann; Dolmage; Wilson and Lewiecki-Wilson).

${ }^{2}$ I use Gee's capital-D “Discourses” to describe an umbrella term for aging Discourse(s) that capture "ways of behaving, interacting, valuing, thinking, believing, speaking, and, often reading and writing" (3), and lower-case "discourses" to refer to participants' speech.

${ }^{3}$ Dobrin describes how some definitions of ecocomposition fail to include writing but opt instead to focus on discourse because of its ability to capture broader cultural trends. In this study, I follow Dobrin's advice to advance an ecology of writing, but to examine writing, I examine discourse about literacy practices that include and inform writing.

${ }^{4}$ Empty parentheses ( ) indicate that a portion of the audio recording was inaudible.

${ }^{5}$ Some age scholars have argued for the concept of "productive aging" wherein older adults contribute to society and the economy even after retirement. Critiques of these arguments have noted the unfairness in labor practices that this approach can bring (King). Because much activist work falls on low-income college students and older adults, this may be a labor issue that is worth exploring in future studies. 


\section{WORKS CITED}

Bowen, Lauren Marshall. "Beyond Repair: Literacy, Technology, and a Curriculum of Aging." College English 74.5 (2012): 437-57. Print.

Brandt, Deborah, and Katie Clinton. "Limits of the Local: Expanding Perspectives on Literacy as a Social Practice." Journal of Literacy Research 34.3 (2002): 337-56. Print. https://doi. org/10.1207/s15548430jlr3403_4

Brueggemann, Brenda Jo. Lend Me Your Ear: Rhetorical Constructions of Deafness. Washington: Gallaudet UP, 1999. Print.

Chivers, Sally. The Silvering Screen: Old Age and Disability in Cinema. Toronto: U of Toronto P, 2011. Print.

Conway, Megan, ed. Review of Disability Studies: An International Journal, 12.2/3 (2016): 1-157. Print.

Cook-Gumperz, Jenny, ed. The Social Construction of Literacy. $2^{\text {nd }}$ ed. Cambridge: Cambridge UP, 2006. Print. https://doi.org/10.1017/CBO9780511617454

Coupland, Nikolas, Justine Coupland, and Howard Giles. Language, Society, and the Elderly: Discourse, Identity, and Ageing. Oxford: Blackwell, 1991. Print.

Cunningham, Jennifer. "Literacy and Identity When Approximating African American Language on Social Network Sites." Journal of Literacy and Technology 15.1 (2014): 54-77. Web. 26 July 2018.

Dobrin, Sidney I. Postcomposition. Carbondale: Southern Illinois UP, 2011. Print.

Dolmage, Jay Timothy. Disability Rhetoric. Syracuse: Syracuse UP, 2014. Print.

Featherstone, Mike, and Mike Hepworth. "The Mask of Ageing and the Postmodern Life Course." The Body: Social Process and Cultural Theory. Eds. Mike Featherstone, Mike Hepworth, and Bryan S. Turner. London: Sage, 1991. 371-89. Print. https://doi.org/10.4135/9781446280546.n15

Fonow, Mary Margaret, and Judith A. Cook. "Feminist Methodology: New Applications in the Academy and Public Policy." Signs: Journal of Women in Culture and Society 30.4 (2005): 2211-36. Print. https://doi.org/10.1086/428417

Gardner-Chloros, Penelope. Code-Switching. Cambridge: Cambridge UP, 2009. Print. https://doi.org/10.1017/CBO9780511609787

Gee, James Paul. Social Linguistics and Literacies: Ideology in Discourses. London: Routledge, 2015. Print. https://doi.org/10.4324/9781315722511

Gilyard, Keith. True to the Language Game: African American Discourse, Cultural Politics, and Pedagogy. New York: Routledge, 2011. Print. https://doi.org/10.4324/9780203834619

Graham, S. Scott. "Object-Oriented Ontology's Binary Duplication and the Promise of ThingOriented Ontologies." Rhetoric, Through Everyday Things. Eds. Scot Barnett and Casey Boyle. Tuscaloosa: U of Alabama P, 2015. 108-24. Print.

Hughes, Bill, and Kevin Paterson. "The Social Model of Disability and the Disappearing Body: Towards a Sociology of Impairment." Disability \& Society 12.3 (1997): 325-40. Print. https://doi.org/10.1080/09687599727209

King, Neal. "The Lengthening List of Oppressions: Age Relations and the Feminist Study of Inequality." Age Matters: Realigning Feminist Thinking. Eds. Toni M. Calasanti and Kathleen F. Slevin. New York: Routledge, 2006. 47-74. Print.

McKee, Heidi, and Kristine Blair. "Older Adults and Community-Based Technological Literacy Programs: Barriers \& Benefits to Learning." Community Literacy Journal 1.2 (2006): 13-39. Web. 26 July 2018. 
Nikander, Pirjo. "Doing Change and Continuity: Age Identity and the Micro-Macro Divide." Ageing \& Society 29.6 (2009): 863-81. Print. https://doi.org/10.1017/s0144686x09008873

Öberg, Peter. “The Absent Body - A Social Gerontological Paradox.” Ageing \& Society 16.6 (1996): 701-19. Print.

Perl, Sondra. "The Composing Processes of Unskilled College Writers." Research in the Teaching of English 13.4 (1979): 317-36. Print.

Powell, Katrina. M., and Pamela Takayoshi. "Accepting Roles Created for Us: The Ethics of Reciprocity." College Composition and Communication 54.3 (2003): 394-422. Print. https://doi.org/10.2307/3594171

Ray, Ruth E. Beyond Nostalgia: Aging and Life-Story Writing. Charlottesville: UP of Virginia, 2000. Print.

Rickert, Thomas. "In the House of Doing: Rhetoric and the Kairos of Ambience." JAC 24.4 (2004): 901-27. Print.

Rubinstein, Robert L., and Kate de Medeiros. “'Successful Aging, Gerontological Theory and Neoliberalism: A Qualitative Critique.” The Gerontologist 55.1 (2015): 34-42. Print. https:// doi.org/10.1093/geront/gnu080

Shakespeare, Tom. “The Social Model of Disability”" The Disability Studies Reader. $3^{\text {rd }}$ ed. Ed. Leonard J. Davis. New York: Routledge, 2010. 266-73. Print.

Siebers, Tobin. Disability Theory. Ann Arbor: U of Michigan P, 2008. Print. https://doi.org/10.3998/ mpub.309723

Sommers, Nancy. "Revision Strategies of Student Writers and Experienced Adult Writers." College Composition and Communication 31.4 (1980):378-88. Print. https://doi.org/10.2307/356588

Swacha, Kathryn Yankura. "Older Adults as Rhetorical Agents: A Rhetorical Critique of Metaphors for Aging in Public Health Discourse." Rhetoric Review 36.1 (2017): 60-72. Print. https:// doi.org/10.1080/07350198.2017.1246013

Syverson, Margaret A. The Wealth of Reality: An Ecology of Composition. Carbondale: Southern Illinois UP, 1999. Print.

Taylor, Mark C. The Moment of Complexity: Emerging Network Culture. Chicago: U of Chicago P, 2001. Print.

Teems, Yvonne R.. “Evidence of New Literacies in Seniors' Health-Related Literacy Practices.” Journal of Literacy and Technology 17.1-2 (2016): 112-35. Web. 26 July 2018.

---. “'My Body Feels Old’: Seniors’ Discursive Constructions of Aging-as-Disabling.” The Review of Disability Studies: An International Journal 12.2-3 (2016): 107-21. Print.

---. “Seniors' Uses of Literacy to Gain Bodily Control in Medical Encounters." Literacy in Practice. Eds. Pamela Takayoshi and Patrick Thomas. New York: Routledge, 2016. 46-57. Print.

Twigg, Julia. “The Body, Gender, and Age: Feminist Insights in Social Gerontology.” Journal of Aging Studies 18.1 (2004): 59-73. Print. https://doi.org/10.1016/j.jaging.2003.09.001

Vieira, Kate. "On the Social Consequences of Literacy." Literacy in Composition Studies 1.1 (2013): 26-32. Web. 26 July 2018. https://doi.org/10.21623/1.1.1.6

Wilson, James C., and Cynthia Lewiecki-Wilson, eds. Embodied Rhetorics: Disability in Language and Culture. Carbondale: Southern Illinois UP, 2001. Print. 